\title{
DESIGNING AND EXECUTING ENVIRONMENTAL-FRIENDLY REINFORCEMENT SYSTEM TO STABILIZE A PROGRESSIVELY FAILED HISTORICAL WATERFALL
}

\author{
Tetsuro ESAKI ${ }^{1}$, Yujing JIANG ${ }^{2}$, Tara Nidhi BHATTARAI ${ }^{3}$, Toshiro MAEDA ${ }^{3}$ and \\ Minoru YOSHIDA ${ }^{4}$
}

\author{
'Member of JSCE, Dr. of Eng., Professor, Inst. of Env. Syst., Kyushu University (Hakozaki 6-10-1, Fukuoka \\ 812-8581, Japan) \\ ${ }^{2}$ Member of JSCE, Dr. of Eng., Associate Professor, Dept. of Civil Eng., Nagasaki University (Bunkyo Machi 1-14, \\ Nagasaki 852-8521, Japan) \\ ${ }^{3}$ Graduate student, Inst. of Env. Syst., Kyushu University (Hakozaki 6-10-1, Fukuoka 812-8581, Japan) \\ ${ }^{4}$ Member of JSCE, M. Eng., Kyushu Electric Power Co; Inc.(Kaneikemachi 2-3-4, Ohita 870-0026, Japan)
}

\begin{abstract}
This paper presents the techniques applied to stabilize a progressively toppling steep rock slope(waterfall) situated about $20 \mathrm{~m}$ downstream from an intake dam. First, using a distinct element analytical model of the slope a suitable rock reinforcement system is designed and analyzed so as to prevent the instabilities of the slope. In addition, a rigorous process of construction works is followed while installing the rock reinforcement elements in order to protect and enhance the geoenvironment of the site. Completion of the construction works has convincingly resulted the original aesthetic of the waterfall assuring its stability during flooding, the commonest natural event of the area, with reasonable cost.
\end{abstract}

Key Words: geoenvironment, rock slope stability, toppling failure, discontinuities, distinct element method, rock reinforcement, aesthetic value

\section{INTRODUCTION}

Designing of slope stabilization measures is an important task in rock engineering. Rock slopes of a site may be composed of single or multiple types of rock masses having similar or dissimilar in origin. Furthermore, they are likely to be dissected by many discontinuities such as bedding, joints, faults and fractures. Accordingly, rock masses of a slope are not continuum and their behavior are dominated by the discontinuities. Because of these features the mode of slope failure is likely to vary from simple plane failure to complex type consisted of combination of plane, wedge and toppling failures. Consequently, the type of counter measures to be applied for slope stabilization works vary from place to place and project to project.

Unstable rock slopes can be stabilized by using various type of retaining walls as has been explained by Hunt(1986)". As described by Stillborg $(1994)^{2}$, rockbolts and cablebolts can also be used to prevent jointed rock masses from plane and wedge failures. 
Describing a limit equilibrium analysis for toppling failure, Goodman and Bray $(1976)^{3)}$ has presented a method of preventing toppling failure of rock blocks by using cablebolts. Since the limit equilibrium method includes only a small number of rock blocks and assumes homogeneous material properties, it is not efficient enough to analyze the reinforcement system designed for the prevention of toppling failure occurred in a discontinuous rock mass. Numerical modeling such as finite element method(FEM) and distinct element method(DEM) have often been used to solve the problems involving heterogeneous or nonlinear material properties. The FEM is well suited to solve linear problems, whereas the DEM is an appropriate tool to deal with highly non-linear problems arose in a rock mass where individual pieces of rock may be free to rotate and translate, and the deformation, that take place at block contacts, may be significantly greater than the deformation of the intact rock. Cundall and Hart (1993) $)^{4}$ have described that the DEM is useful in analyzing progressive, large-scale deformation of discontinuities and also to study reinforcement system and surface support in a rock mass. But Hoek et al. (1995) $)^{\text {) }}$ has mentioned that further experience in the application of this method to practical design situation is still required so as to understand where, when and how the DEM could be applied properly.

The aim of this paper is to present a method of designing reinforcement system by using a DEM analytical model so as to stabilize a progressively toppling steep rock slope(waterfall) situated about 20 $m$ downstream from an intake dam. In addition, a rigorous process of construction works is also described in order to protect and enhance the geoenvironment of the site while installing the rock reinforcement elements.

\section{GEOTECHNICAL DESCRIPTIONS OF THE INVESTIGATED SITE}

\section{(1) Site characterization}

Chinda Waterfall is the site of this research and it forms a steep cliff(height: $28 \mathrm{~m}$ and width: $110 \mathrm{~m}$ ) on
Table 1 Joint material properties established by the direct shear test.

\begin{tabular}{|l|c|c|c|c|}
\hline \multirow{2}{*}{ Properties } & \multicolumn{2}{|l|}{ Horizontal joint } & \multicolumn{2}{|c|}{ Vertical joint } \\
\cline { 2 - 5 } & AWT & BWT & AWT & BWT \\
\hline $\begin{array}{l}\text { Shear stiffness } \\
(\mathrm{MPa} / \mathrm{m})\end{array}$ & 2880 & 1090 & 449 & 481 \\
\hline $\begin{array}{l}\text { Normal stiffness } \\
(\mathrm{MPa} / \mathrm{m})\end{array}$ & 10800 & 9980 & 8670 & 11000 \\
\hline $\begin{array}{l}\text { Cohesion } \\
(\mathrm{MPa})\end{array}$ & 0.039 & 0.232 & 0.011 & 0.113 \\
\hline $\begin{array}{l}\text { Friction angle } \\
\text { (Degrees) }\end{array}$ & 54 & 3.3 & 50 & 30 \\
\hline $\begin{array}{l}\text { Dilation angle } \\
\text { (Degrees) }\end{array}$ & 2.3 & 2.3 & 2.3 & 2.3 \\
\hline $\begin{array}{l}\text { Tensile strength } \\
\text { (MPa) }\end{array}$ & 0.15 & 0.15 & 0.15 & 0.15 \\
\hline
\end{tabular}

AWT: above water table; BWT: below water table

Table 2 Block(intact) material properties.

\begin{tabular}{|l|l|l|l|}
\hline \multicolumn{1}{|c|}{ Properties } & $\begin{array}{l}\text { Welded } \\
\text { tuff }\end{array}$ & $\begin{array}{l}\text { Gravel } \\
\text { deposit }\end{array}$ & $\begin{array}{l}\text { Dam/apron } \\
\text { (concrete) }\end{array}$ \\
\hline Density $\left(\mathrm{N} / \mathrm{m}^{3}\right)$ & 22300 & 18000 & 20800 \\
\hline $\begin{array}{l}\text { Bulk modulus } \\
\text { (MPa) }\end{array}$ & 16800 & 155 & 8360 \\
\hline $\begin{array}{l}\text { Shear modulus } \\
\text { (MPa) }\end{array}$ & 6460 & 51 & 7160 \\
\hline $\begin{array}{l}\text { Cohesion } \\
(\mathrm{MPa})\end{array}$ & 2.45 & - & 1.47 \\
\hline $\begin{array}{l}\text { Friction angle } \\
\text { (Degrees) }\end{array}$ & 45 & 46 & 40 \\
\hline $\begin{array}{l}\text { UCS (MPa) } \\
\text { Tensile strength } \\
(\mathrm{MPa})\end{array}$ & 1.96 & - & 1.08 \\
\hline
\end{tabular}

UCS : Unconfined compressive strength

the bed of the Ohono river located in Kyushu island of Japan. A small, concrete, intake dam (height: 6.0 m) constructed 90 years ago is located about $20 \mathrm{~m}$ upstream from the cliff. The space between the cliff and the dam forms the dam apron covered by a concrete layer. Welded tuff, derived from Aso Volcano 20 - 80 thousands years ago, is the rock type of the 
cliff and underlying it are palaeo gravel deposit and sandstone, Cretaceous, successively. The welded tuff is horizontally stratified and is characterized with vertical shrinkage joints developed during cooling of lava. The cliff is developed along the vertical joints. At the cliff's face, the welded tuff and the palaeo gravel deposit are 25 and $5 \mathrm{~m}$ thick, respectively. The sandstone forms the basal part of the cliff and is exposed a little at its foot. The stress-deformational behavior of joints associated with the welded tuff was investigated by laboratory shear test and the results are shown in Table 1. Similarly, the strength and deformability of the block(intact) materials of the welded tuff and the concrete(dam) were from uniaxial tests. In case of gravel deposit, it was established based on the standard penetration test using the method described by Kitazawa et al.(1959) ${ }^{6}$. As evident from Table 2, the concrete used while constructing the dam and the apron about ninety years ago appears to be of low quality.

\section{(2) Slope stability problems}

Slope instability problem of the cliff was noticed since many years, but it was not taken seriously as it was occurring away from the places of public interest. There has been no any sign of circular failure as contributed by the fact that the rock mass is consisted of pillar like rock blocks in which toppling forms the prominent failure pattern. A long time back, the cliff(Chinda waterfall) and Hirai river waterfall were situated together, but due to instabilities initiated at the cliff face they are far apart now. The failure in the cliff has been extended about $240 \mathrm{~m}$ upstream during last 150 years revealing the rate of failure to be about 1 to $2 \mathrm{~m}$ per year ${ }^{7}$. But for the last 90 years(after construction of the dam), the failure rate has been estimated to be about $0.5 \mathrm{~m}$ per year. The failure process occurs specially during rainy seasons and the failed rock blocks, initially accumulated at the bottom of the cliff, appear to be transported downstream by the river water during flooding creating a situation for further failure of the slope. This phenomena have deteriorated the aesthetic value of the waterfall and also pose a serious threat to the stability condition of the intake dam. In addition, since the cliff is almost

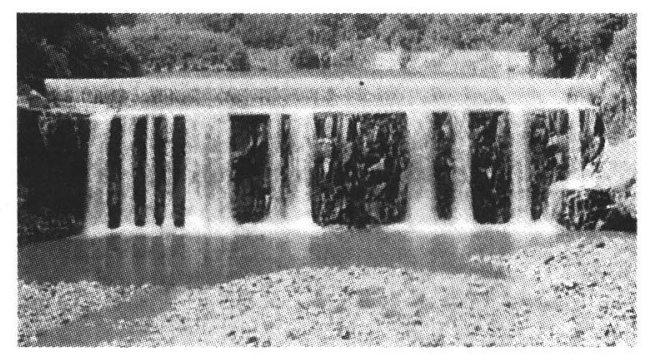

(a) Original or old scenery produced by computer graphics.

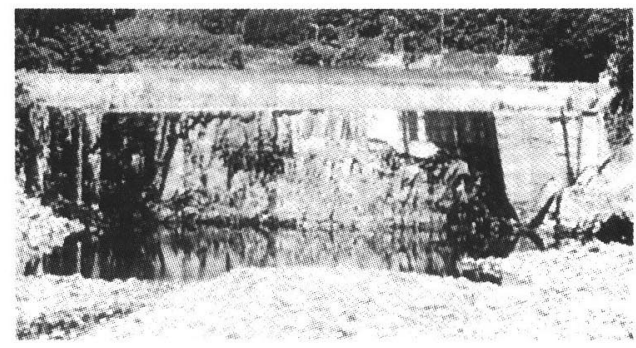

(b) Present scenery.

Fig.1 Scenery of the waterfall.

vertical, it also makes the rock reinforcement works very difficult.

\section{EVALUATION OF AESTHETIC RESOURCES}

Prior to design of a rock reinforcement system so as to protect the waterfall in its natural form preventing it from further toppling failure, the cliff was evaluated in order to reveal its aesthetic resources. Considering the local residence's views, studying old aerial photographs and also a historical painting ${ }^{R}$, it was understood that the cliff was very famous since historical past containing eleven different waterfalls on the same slope as shown in Fig.1 (a) constructed by computer graphics based on a historical record. Since the cliff forms the river bed, natural event like flooding certainly contributes for failure and thus promote degradation of the scenery. As the failure was identified mainly related to the geometrical and mechanical properties of discontinuities along with the quantity of river water (Esaki et al., 1998) ${ }^{9}$, the physical and chemical properties of the welded tuff as 
well as the quality of river water and groundwater and their influence on the degradation of the scenery can be assumed to be minimum and has therefore not been included in this research.

The above mentioned facts clearly imply that the eleven waterfalls, which do not exit now due to the failure of the cliff as shown in Fig.1 (b), have to be rehabilitated resembling their beauty as close as mentioned in Fig.1 (a) so as to maintain its aesthetic value. As the floods are the most common natural events of the area, the stabilization works should be aimed to maintain the eleven waterfalls preventing further instabilities of the cliff during flooding situations.

\section{ROCK REINFORCEMENT SYSTEM}

\section{(1) Selection criterion}

A reinforcement system can be considered environmental-friendly if it satisfies the following points: (1) it assures the long term stability of the slope even during most likely natural events, (2) it does not change the landform abruptly and maintains the aesthetic value of the site remarkably, (3) it causes minimum disturbances to the surrounding environment and does not pose serious threat such as injuries to the workers during its installation, (4) its efficiency does not reduce with time and can be monitored with simple means and (5) as far as possible the reinforcement elements should be in harmony with the local traditions. In addition, it has to be of reasonable cost.

\section{(2) Designing concept}

It has been a tendency to construct various type of retaining walls to provide counter measures against toppling failures in rock masses. Such approach certainly provides stability to the slope but at the same time it may also cause some negative impacts on the environment of the construction site depending on the nature of the project being treated. For example, the retaining wall may change the scenery of the site and thus causes negative impact on the aesthetic value of the area. To overcome this inherent deficiency of the retaining walls, a rock reinforcement system consisted of rockbolts and a concrete base structure is suggested.
Collection of joint samples and engineering geological data base from surface exposure and borehole cores

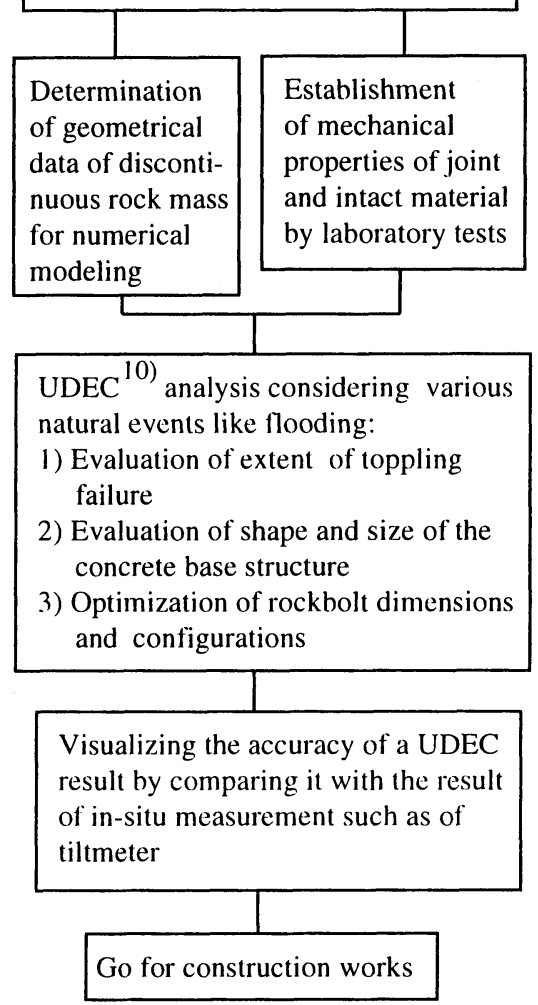

Fig.2 Steps involved in the process of rock reinforcement analysis.

It is particularly suitable for steep, high(say $30 \mathrm{~m}$ ) rock slopes such as the case of a river bank. The concrete base structure is constructed at the lower part, whereas the rockblots are installed for the upper part of the slope. The main idea behind this concept is that the basal part of the slope has to be supported firmly to prevent sliding and overturning of the slope. Once the basal part becomes stable, the instability of the upper part can be prevented by fastening some rock blocks together using rockblots so that the width/height ratio of the rock blocks become larger to prevent toppling failure.

\section{(3) Analysis method}

This method takes into account of the geology of the site and mechanical properties of the discontinuities to identify the extent and mode of failure of the slope and subsequently to optimize the amount, length and 


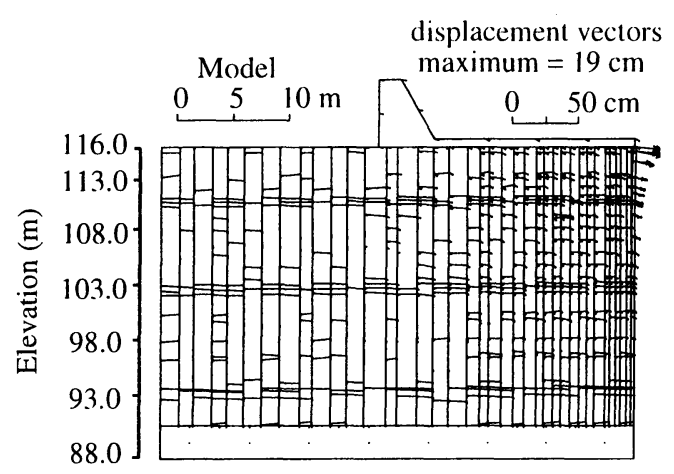

(a) Displacement vectors developed in a UDEC model during flooding.

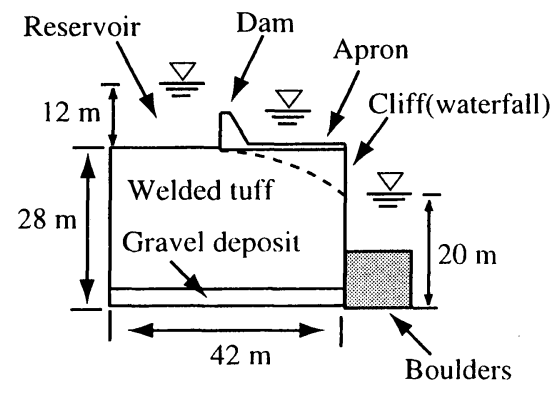

(b) Water table in river during assumed flooding.

Fig.3 Result of the UDEC analysis before applying the rock reinforcement elements.

configuration of the rockblots and also the shape and size of the concrete base structure by numerical simulation. In addition, it also analyzes the efficiency of the reinforcement elements under various natural events such as flooding. The basic steps involved in the process of reinforcement analysis are summarized in Fig.2.

\section{a) Failure mechanism}

Prior to model construction, surface mapping and fourteen exploratory drillings were carried out to establish the value of trace length, spacing and orientation of joints present in the welded tuff. Both methods indicated that the welded tuff is dissected by two sets of joints: horizontal and vertical. The spacings of the vertical joint vary from 0.29 to $1.16 \mathrm{~m}$ in and around the cliff and attain nearly a constant value of about $1.74 \mathrm{~m}$ around the dam and the reservoir. Its trace length is more than $24 \mathrm{~m}$ and thus extends all along the cliff. Similarly, the spacings of the horizontal joint also vary from 0.3 to $3.2 \mathrm{~m}$ in and around the cliff and are in the range of 1.74 to $4.64 \mathrm{~m}$ around the dam and the reservoir. Unlike the case of the vertical joints, its trace length generally varies between 0.29 to $2.03 \mathrm{~m}$ in and around the cliff and they are in the range of 1.45 to $2.03 \mathrm{~m}$ around the dam and the reservoir. But it is important to note that the spacing of the horizontal joints at three different elevations $(93,102$ and $110 \mathrm{~m}$ ) are very narrow(about $0.3 \mathrm{~m}$ ) and at these location the trace length is also larger ranging from about 2 to $6 \mathrm{~m}$. Based on these values a distinct element analytical model of the cliff was constructed by using UDEC and the model was run to understand the mode and extent of the failure with various situations(Esaki et al., 1998) ${ }^{y}$. During analysis the left boundary was assumed to have roller boundary whereas the base of the model was assumed to have fixed boundary. As shown in Fig.3 (a), the UDEC result suggests that the failure process initiates at the upper part of the cliff which gradually extends towards the dam during flooding event in which the level of water on the reservoir and at the bottom of the waterfall were assumed to be $12 \mathrm{~m}$ and $20 \mathrm{~m}$, respectively as shown in Fig.3 (b) based on the flooding records. Further, the failure appears to be of toppling type, because the dispalacement vectors developed at the slope face decreases gradually downward. This result can be explained by assuming the fact that the width/ height ratio(about $0.3 / 3.0$ ) of the rock blocks situated at the cliff face is not larger enough to resists rotation of the block caused by pore water pressure and flood water.

\section{b) Reinforcement optimization}

As already mentioned above, the rock reinforcement system is consisted of a concrete base structure and rockbolts for the lower part and the upper part of the cliff, respectively. The concrete base structure was intended to prevent sliding and overturning which may initiate near cliff's base around the contact between welded tuff and palaeo gravel deposit during flooding in which the accumulated boulders at the cliff's bottom are likely to move downstream with flood water. Besides, it was also aimed to prevent further scouring of cliff's base(palaeo gravel deposit) due to eroding action of waterfall. To meet these requirements the 


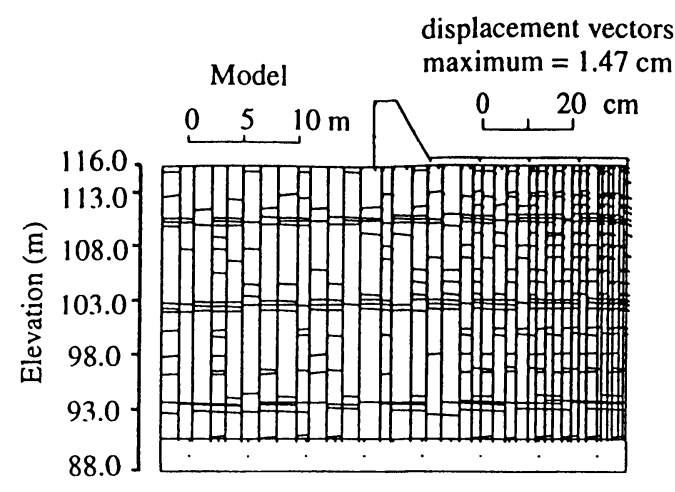

(a) Displacement vectors developed in a UDEC model during flooding.

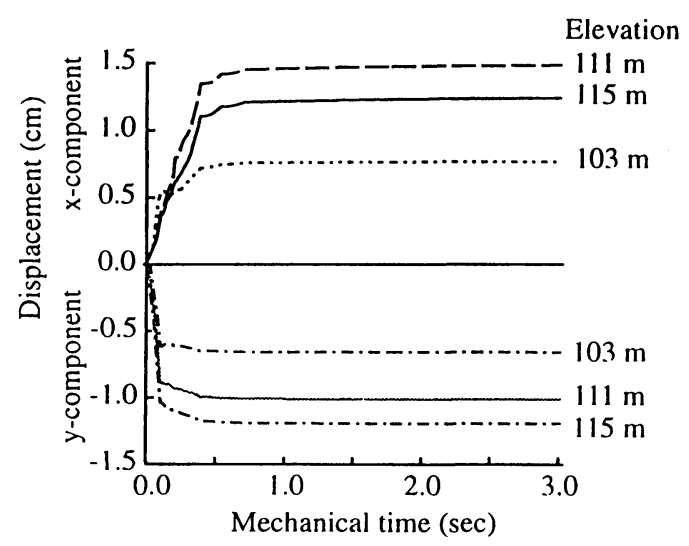

(b) $x$ - and y-component of displacement predicted by UDEC at various elevations of the cliff face during flooding.

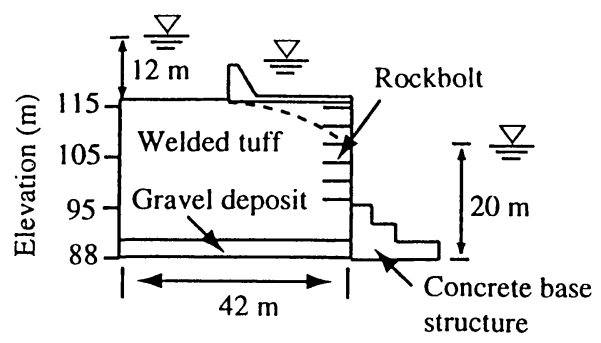

(c) Rock reinforcement elements and position of water table in river during assumed flooding.

Fig.4 Results of the UDEC analysis after applying the rock reinforcement elements.

concrete base structure was designed as shown in Fig.4 (c). While deciding rockbolt length and its vertical spacing two main points were taken into consideration. Firstly presence of loosen rock blocks in the immediate vicinity, upto about $5 \mathrm{~m}$ upstream, of the cliff and secondly the height, about $3 \mathrm{~m}$, of rock blocks situated at the cliff face. Taking these points into account and also utilizing the available techniques of rock bolting, rockbolts length and their vertical spacing were decided to be $5 \mathrm{~m}$ and $3 \mathrm{~m}$, respectively. Since the joints that gave rise pillar shaped rock blocks are vertical the rockbolts were decided to be installed horizontally.

UDEC analysis was performed to evaluate whether the proposed rock reinforcements are enough to prevent instabilities of the cliff during flooding. As a result, it was understood that the instabilities of the cliff can be improved satisfactorily as revealed by Fig.4 (a) and (b). The DEM model shown in Fig.4 (a) predicts stable condition of the cliff as indicated by the constant value of displacement vectors developed during model run and also by the constant values of $\mathrm{x}$ - and $\mathrm{y}$-component of dispalcement monitored at various elevations of the cliff face as shown in Fig.4 (b). Such results may be interpreted considering the fact that the rockbolts firmly fasten the rock blocks of the slope face resulting them to behave as a single block of larger width/height ratio(5.0/3.0) which, in turn, increases the resisting force and prevent the instability.

\section{ROCK REINFORCEMENT ELEMENT INSTALLATION WORKS}

\section{(1) Installation sequence}

Construction process is started considering three basic points namely, construction plan, safety measures and aesthetic consideration simultaneously. The main purpose of this sequence is to complete the construction works enhancing the geoenvironment of the site and assuring the safety of the workers. Besides, it was also expected to complete the project with minimum construction cost. The concrete base structure was constructed first and then the rockbolts were installed. The basic steps involved in the execution of the reinforcement elements are shown in Fig.5.

\section{(2) Safety measures}

To prevent likely disaster during construction works, 


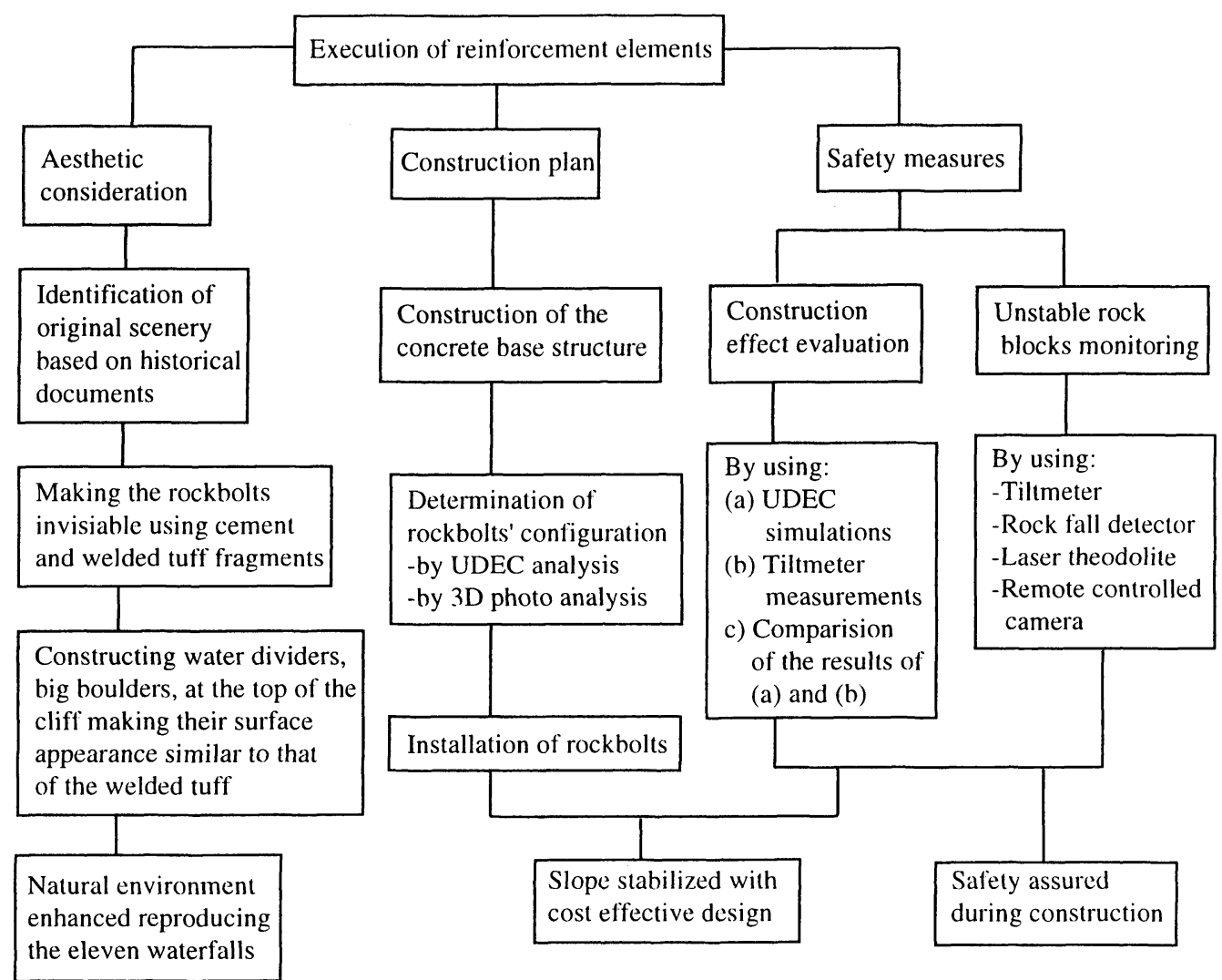

Fig.5 Steps involved in the execution of reinforcement elements

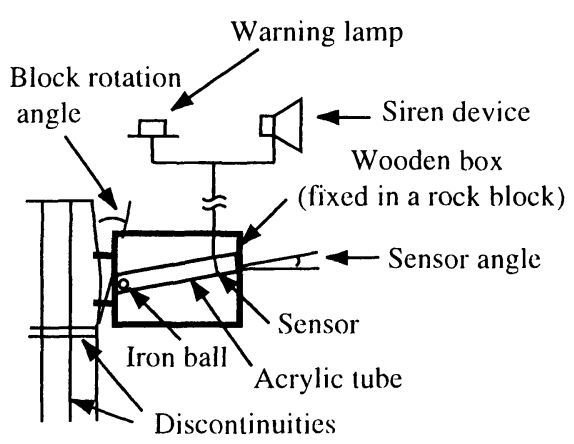

Fig.6 Specially designed rock fall detector installed at the slope face to monitor rock block rotation.

five different devices were employed namely, (1) specially designed rock fall detector ${ }^{7)}$ to understand the rock block rotation, (2) a remote controlled laser theodolite to monitor the distance of the slope from a point, (3) a remote controlled camera to inspect the slope from a safe distance, (4) a tiltmeter to record the

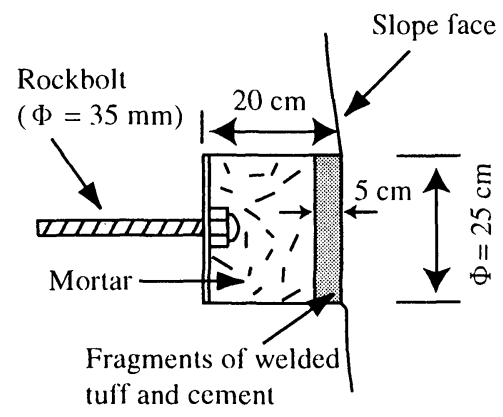

Fig.7 Technique of rockbolt installation.

movement of the slope, and (5) a water level gauge to monitor the level of water in the reservoir. The specially designed rock fall detectors were installed at potentially unstable zones where general situation was such that failure will initiate if rock blocks rotate more than 5 degrees. But the angle of sensor(Fig.6) was determined in such way that it immediately gives siren if the rock block rotates more than one degree to 

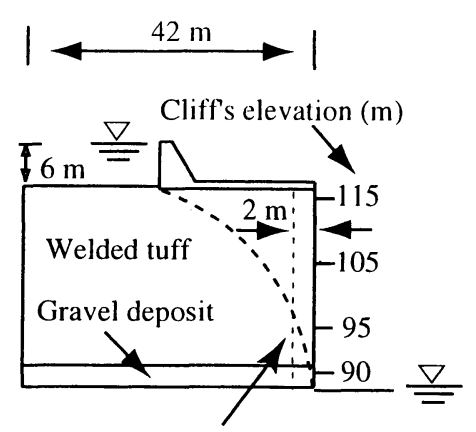

Measuring line(position of tiltmeter)

(a) Position of water table in river during tiltmeter and UDEC investigation.

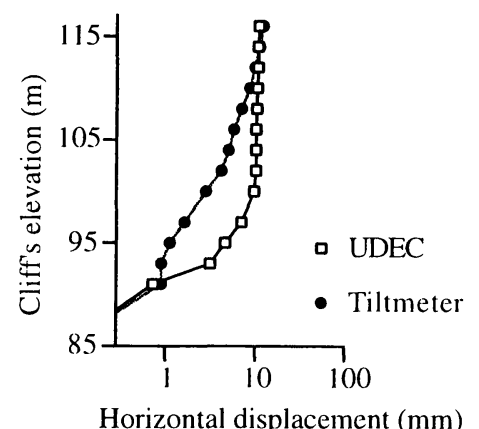

(b) Result of UDEC analysis and tiltmeter.

Fig.8 Predicted(UDEC) and measured(Tiltmeter) horizontal displacement of the cliff.

provide enough safety during construction.

\section{(3) Bolt installation technique}

Using sky drill, which can work at upto $30 \mathrm{~m}$ high from the ground, $5 \mathrm{~m}$ long holes(diameter:70 $\mathrm{mm}$ ) were drilled. Afterwards, expansion shell anchored rockbolts(diameter:35 $\mathrm{mm}$ ) were inserted into the holes followed by rotating them so as to expand the shell against and into the wall of the borehole. Later, the void between the rockbolt and the borehole was grouted. In addition, potentially unstable zones(places of overhanging blocks and open joints) and structurally important area(where joint spacing and orientation pose additional problems) were also identified by $3 \mathrm{D}$ photo analysis. For each $2.5 \mathrm{~m}^{2}$ of the potentially unstable zone one rockbolt was installed, whereas in the case of structurally important area it was $5.0 \mathrm{~m}^{2}$ per rockbolt. For the rest of the area, one rockbolt was
Table 3 Advantages of the proposed reinforcement system(concrete base structure and rockbolts) over retaining wall.

\begin{tabular}{|l|l|l|}
\hline $\begin{array}{l}\text { Items for } \\
\text { comparision }\end{array}$ & $\begin{array}{l}\text { Retaining } \\
\text { wall }\end{array}$ & $\begin{array}{l}\text { Concrete base } \\
\text { structure and } \\
\text { rockbolts }\end{array}$ \\
\hline $\begin{array}{l}\text { Estimated } \\
\text { construction cost }\end{array}$ & $\begin{array}{l}2.92 \text { billions } \\
\text { Japanese Yen }\end{array}$ & $\begin{array}{l}0.86 \text { billion } \\
\text { Japanese Yen }\end{array}$ \\
\hline $\begin{array}{l}\text { Aesthetic } \\
\text { value }\end{array}$ & degrade & enhance \\
\hline $\begin{array}{l}\text { Harmony } \\
\text { with the local } \\
\text { traditions }\end{array}$ & negative & positive \\
\hline
\end{tabular}

installed per $7.5 \mathrm{~m}^{2}$ of the slope(Yoshida et al., 1998) ${ }^{7}$. As already mentioned above, based on the UDEC results the rockbolts were applied maintaining their vertical spacing of $3 \mathrm{~m}$ in each case.

\section{(4) Aesthetic consideration}

The rock reinforcement elements were designed in such a way that they do not abruptly modified the scenery of the site because the concrete base structure was designed to be always situated below the river water level and the rockblots were also installed in such way that their face plate and the nut were made invisible as shown in Fig.7. In addition, the concrete blocks used to subdivide the waterfall at the top of the cliff(see Fig.9) were also prepared in such a way that they resemble exactly same appearance(surface texture) as that of the welded tuff.

\section{(5) Stability assurance}

To construct the concrete base structure, the rock boulders accumulated at the base of the cliff were taken out and the level of the river water was also lowered down to the river bed level as shown in Fig.8 (a). The response of the cliff for this situation was investigated by UDEC analysis and also by a tiltmeter recording horizontal displacement along the measuring line shown in Fig.8 (a). As represented by Fig.8 (b), the results obtained with these analysis are comparable.

After completion of the construction works, the cliff has been continuously monitoring by a tiltmeter and also by a rock mass deformation meter so as to 


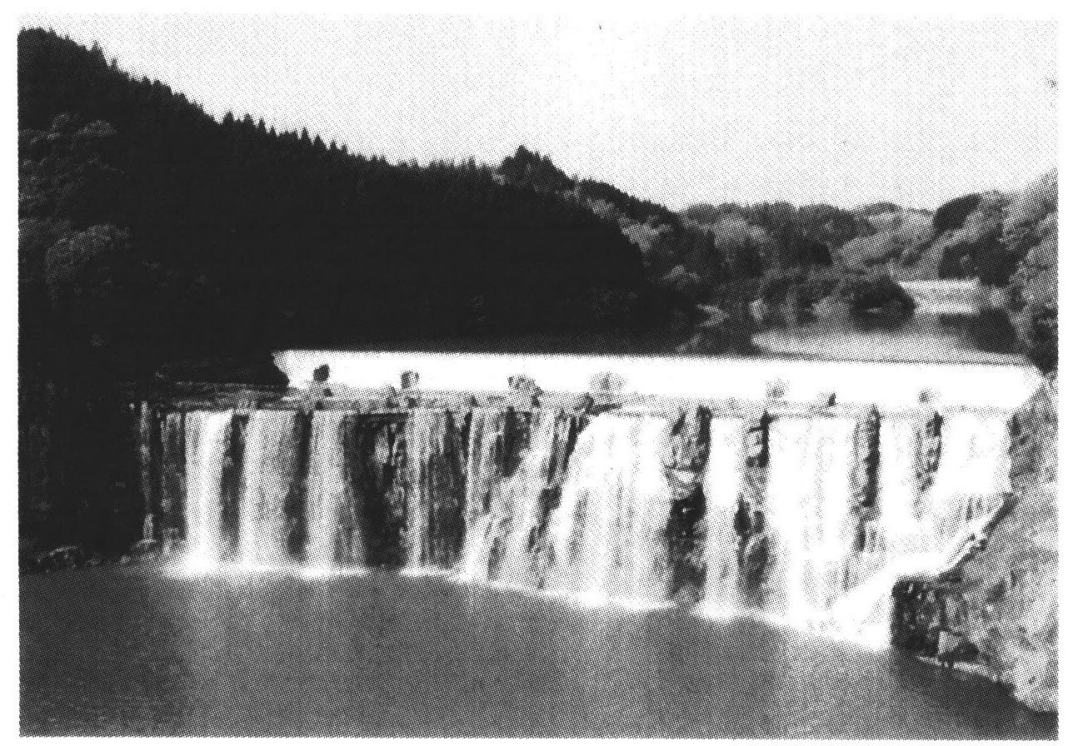

Fig.9 Scenery of the waterfall after applying the rock reinforcement elements.

understand the long term stability of the cliff during various flooding events. These equipments have shown no any serious sign of instabilities even during flooding events of last years(Yoshida et al., 1998) ${ }^{7}$.

\section{(6) Economic consideration}

The construction works were completed in 1997 and the advantages of the proposed reinforcement system over retaining wall are shown in Table 3 which indicates that the construction cost is one third cheaper than the traditional method of rock reinforcement with an abutment or retaining wall. The specially designed rock fall detector employed to monitor rock block rotation costs about seventy thousands Japanese Yen per set which is also very cheaper in comparing with the current equipments employed for the same purpose.

\section{(7) Results}

The final scenery of the site after completion of the construction works is shown in Fig.9 which convincingly indicates that the applied rock reinforcement system is capable of rehabilitating all the eleven waterfalls to their original condition. In addition, the reinforcement system is not only cheaper but also environmental- friendly because it assures the stability of the slope even during flooding seasons, the commonest natural event of the area, and are also invisible to human eyes. All the equipments employed for the safety measures effectively provided warning information to the workers in case the rock blocks were about to fall down and thus they significantly helped to avoid the lose of life and property during construction works.

\section{CONCLUSIONS}

In this paper, DEM analytical models have been used to study rock reinforcement against toppling failure occurred in a slope(waterfall) of discontinuous rock mass. In addition, a rigorous process of construction works has also been followed in order to protect and enhance the geoenvironment of the site while installing the rock reinforcement elements.

Results of the DEM analysis reveal that the instabilities of the slope can be improved satisfactorily by using rockbolt reinforcement and a concrete base structure. Following the results the upper part of the slope was reinforced by installing five-meter-long rockbolts horizontally maintaining their vertical spacing of three meters, whereas the lower part of the slope was supported by a concrete 
base structure. Completion of the rock reinforcement element installation works has convincingly resulted the original aesthetic of the waterfall assuring its stability during flooding, the commonest natural event of the area.

These results are in agreement with the fact that the rockbolts have firmly fastened the rock blocks of the slope face resulting them to behave as a single block of larger width which, in turn, increases the resisting force and prevent the instability.

These findings imply that the DEM can be used effectively to study rock reinforcement against toppling failure occurred in slopes of discontinuous rock masses. But in order to achieve result of acceptable quality, mechanical properties of discontinuities and also the input data needed to construct models should be established by considering field situations confidently.

ACKNOWLEDGEMENTS: The authors gratefully acknowledge Kyushu Electric Power Co., Inc., Japan for providing financial support to carry out this study. We also would like to thank Mr. Naoto Goto, Research Institute of Kajima Corporation, Tokyo for his assistance in UDEC calculation.

\section{REFERENCES}

1) Hunt, R.E.: Geotechnical Engineering Techniques and Practices, McGraw-Hill, New York, 1986.

2) Stillborg, B.: Professional Users Handbook for Rock Bolting, 2nd ed., Trans Tech Publication, Germany, pp. 58-62, 1994.

3) Goodman, R.E. and Bray, J.W.: Toppling of Rock Slopes, Proc. Speciality' Conference on Rock Engineering for Foundation and Slopes, Boulder, Colorado, ASCE, pp. 201 234, 1976.

4) Cundall, P.A. and Hart, R.D.: Numerical Modeling of Discontinua, in Comprehensive Rock Engineering, Vol. 2, J.A. Hudson, ed., Oxford: Pergamon Press, pp. 231-243, 1993.

5) Hock, E., Kaiser, P.K. and Bawden, W.F.: Support of Underground Excalations in Hard Rock, Balkema, Rotterdam, pp.75-81, 1995.

6) Kitazawa, G., Takeyama, K., Suzuki, K., Ogawara, H. and Osaki, T.: Tokyo Jibanzu (in Japanese), Gihodo, pp. 18-19, 1959.

7) Yoshida, M., Takamori, S. and Sasada, T.: Design and Execution of a Reinforcement System for the Steep Rock Slope(Chinda Waterfall) Situated Close to the Intake Dam of Chinda Hydroelectric Power Plant, Electric Power Civil Engineering (in Japanese), Vol. 7, No. 276, pp. 29-33, 1998.

8) The Yomiuri Shimbun(Japanese daily), evening ed., Apr.15, 1998.

9) Esaki, T., Jiang, Y., Bhattarai, T.N., Nozaki, A. and Mizokami, T.: Stability Analysis and Reinforcement System Design in a Progressively Failed Steep Rock Slope by the Distinct Element Method, Int. J. of Rock Mech. \& Min. Sci. 35: 4-5, Paper No. 31, 1998

10) Itasca Consulting Group, Inc., UDEC(Universal Distinct Element Code) Version 3.0, 1996.

(Received May 11, 1999)

直立岩盤斜面の補強工事の設計，施工と環境への配慮

江崎哲郎・蒋宇静·Tara Nidhi BHATTARAI ·前田俊郎・吉田實

本研究では, 歷史的に重要な滝をなす直立岩盤斜面を補強するための設計と施工を行った。すなわち, 不 連続性岩盤斜面に生じるトップリング破壊に対する定定解析，補強工法の設棓，選定方法を提案し，施工

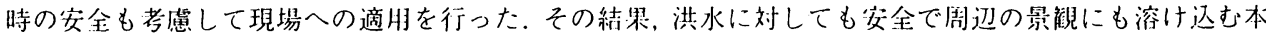
来の美しい淁の詈観がよみがえった。また施工費肞も少なく抑えることができた。 